\title{
LINGUISTIC DIVERSITY IN BOOK AND JOURNAL PUBLICATIONS ON SARAWAK, 1810-2016
}

\author{
Arndt Graf \\ Department of Southeast Asian Studies \\ Goethe University of Frankfurt, Germany \\ (argraf@rz.uni-frankfurt.de) \\ DOI: https://doi.org/10.22452/brj.vol13no1.4
}

\begin{abstract}
This paper focuses on linguistic choice in book and journal publications on Sarawak. It is found that in general, English has lost its formerly quasi-monopoly in book publications on Sarawak in the period since the formation of Malaysia (1963-), in particular since the 1980s, although it is still of great importance. Malay has become an increasingly relevant language of book publications on Sarawak. There is also an interesting body of book publications in Chinese and Austronesian languages from Sarawak, including in Iban since the mid-2000s. Overall, there seems to be a rather stable equilibrium of languages since the early 2000s. In terms of academic journal articles on Sarawak as represented in the Malaysian Abstracting and Indexing database MyCite, a similarly stable equilibrium between English and Malay has been found. The specialised scholarly discourse on Sarawak in the examined contributions from the humanities and the social sciences is mostly conducted in Malay, not English, while a few publications in the social sciences and in all of the sciences, engineering, and medicine, are in English. This linguistic diversity in publications on Sarawak implies that scholars working on Sarawak should be fluent in more than one language.
\end{abstract}

Keywords: Sarawak, linguistic diversity, English, Malay, Chinese, Iban, humanities, social sciences

\section{Introduction}

Since the global university rankings started to appear in the early 2000s, more and more ministries of higher education and university leaders in Southeast Asia are attempting to increase their respective ranking position by increasing the number of their relevant publication output. Due to the methodology of most global university rankings, the relevant publications are those covered by the Abstracting and Indexing databases employed for the rankings, notably the Web of Science 
(WoS) which is known in many parts of Southeast Asia under their earlier acronym ISI (Institute for Scientific Information). This American database almost exclusively focuses on English-language publications. ISI does not cover any publications in languages from Southeast Asia, e.g. Indonesian, Vietnamese, Malay, or Thai. (Graf, 2009, 2010, 2011). Hence, in the current phase of Higher Education in Southeast Asia, the academic use of the national languages of Southeast Asia is challenged in terms of publications and increasingly also as a language of instruction. This has potentially serious consequences for the status of the national languages of Southeast Asia, and their significance for questions of identity, nation-building and political-cultural and political stability in heterogeneous multi-lingual societies.

This paper focuses on a case from Malaysian Studies, namely linguistic choice in book and journal publications on Sarawak. The main question is which languages of publications on Sarawak have developed in the past and whether there is already an impact of the global push towards English as the language of academic publications. My case study covers in its first part all book publications with the word "Sarawak" in the title from the early $19^{\text {th }}$ century to the present (1810-2016), as they are represented in thousands of international library catalogues made accessible through WorldCat. As of February 2017, Worldcat gave access to 390,029,610 bibliographic records in 491 languages and dialects ("Inside WorldCat", n.d.). I am aware that there might be other publications that deal with aspects of Sarawak but do not feature that name in the title of the book. This includes book chapters on Sarawak in collective volumes. The results of my search can, therefore only indicate rather general trends of language use. On the other hand, the term "Sarawak" has been used consistently from the 19th century until today, which makes the search results more consistent than if I had selected other parts of Malaysia, or more specifically, Borneo, that underwent changes of their names.

I then investigate the trends of book publications in the period since the end of World War II in 1945 to the present day (2016), with the Malaysian Academic Library Union Catalogue, MALCat, considering that in the post-war and post-independence period since Sarawak co-formed the Federation of Malaysia 1963, Malaysian libraries are globally the most comprehensive in the field of Sarawak Studies. The Malaysian Union Catalogue MALCat gives access to the catalogues of 24 Malaysian libraries with 4,419,000 books and journals and 100,000 electronic resources (Malaysian Academic Library Union Catalog [MALCat], n.d.). This is complemented with an analysis of the linguistic choice of journal articles on Sarawak in Malaysian journals, as documented by the bibliographic website MyCite. MyCite is provided by the Malaysian Ministry of 
Higher Education and gives the reference of and access to journals published with public funding of the Federal government (Malaysian Citation Index [MyCite], n.d.).

\section{Background}

I would like to begin the discussion in this paper with some remarks on "linguistic fatalism", as I would like to call the wide-spread attitude that English is the language of globalisation and that the entire world is entering a phase where languages other than English (LOTE) are increasingly obsolete. First of all, I would like to recall that globalisation processes are not a new phenomenon. Also, in previous historical periods, there have been phases of increased market integration. An example from pre-colonial Southeast Asia is the time when Malacca flourished as a major hub between East Asia, Southeast Asia, the Indian Ocean, and beyond. This intense multilingual and multicultural contact brought with it widespread multilingualism that even affected images of heroic or legendary figures. As Muhammad Haji Salleh (2003, p. 4) has pointed out, according to the Hikayat Hang Tuah, Hang Tuah, the hero from $14^{\text {th }}$ or $15^{\text {th }}$ century Malacca, was fluent in twelve languages, including Javanese, Chinese, Indian languages, Arabic etc. (Graf, 2015). Multilingualism and cosmopolitanism is hence part of the history and tradition of the Malay world. Only later on, with the increasing influence of European powers, the linguistic habits and cultural horizons of Southeast Asians were profoundly altered, to follow the argumentation of Syed Hussein Alatas in his seminal work The Myth of the Lazy Native (Syed Hussein Alatas, 1977).

The point here is that the history of Southeast Asia can be seen in an exemplary way for general patterns of linguistic shifts: Phases of increased market integration and multilingualism do not last forever. Rather, historically there were always also periods of shrinking market integration, or of (forced) new linguistic and cultural horizons. The lesson is that also the role of English as the major world language of the $20^{\text {th }}$ century might change in the $21^{\text {st }}$ century, including in Southeast Asia. Globalisation is not a linear process, and the current global role of English might change in the future. Even in the $20^{\text {th }}$ century, the integration of the world's markets was severely affected from the early 1930s onwards for at least 20 years, as Seidel and Chamdy (2016) from the Brookings Institution highlighted in their study on "Donald Trump and the future of globalisation". Protectionism and the global wars of the 1930s and 1940s were the main reasons. The key point in the study by Seidel and Chamdy is that in the case of possibly increased American protectionism under President Trump and global reactions to that, earlier 
optimism concerning the future of globalisation has to be re-evaluated, giving way to much more concerned or even pessimistic views. This, of course, would also affect the linguistic map of the world's most commonly used languages.

Figure 1: Globalisation Trends, 1879-2015

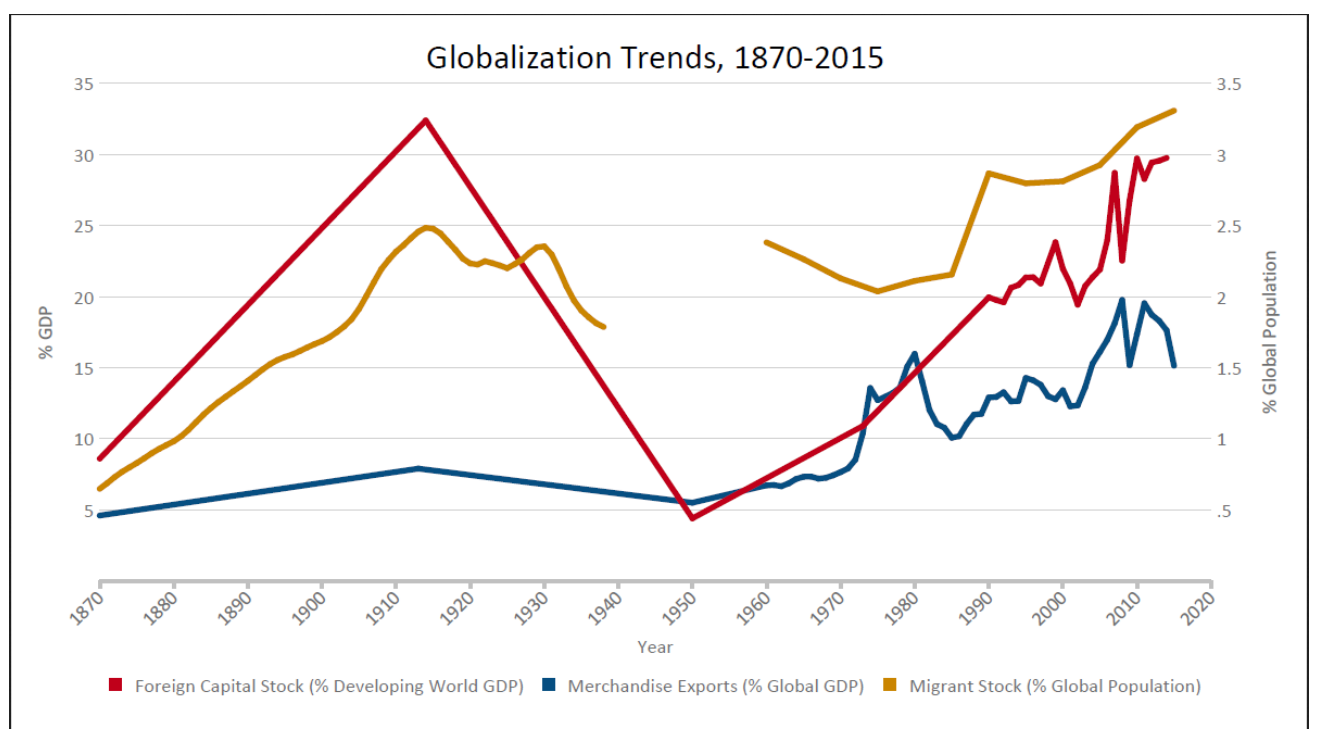

(Source: Seidel and Chandy [2016].)

Even without such political shocks, in the current era of the Internet, the global role of the world's languages is rapidly shifting. One driving factor is the increasing role of e-commerce, business conducted with the support of the Internet. The T-Index produced by the website of Translated (n.d.) attempts to track and forecast trends of the economic relevance of languages in the digital world. Accordingly, English was 2017, the language of $42.5 \%$ of e-commerce sites. However, its relevance is rapidly declining. By 2021, according to the T-Index, the percentage of English will shrink to $34.7 \%$. This is due to the relative rise of other languages used in e-commerce. Chinese is currently the fastest-growing competitor of English, with a predicted increase from $9.3 \%$ in 2017 to $13.7 \%$ in 2021, but also Spanish, Portuguese, Russian, Arabic, and Malay/Indonesian are gaining economic relevance. On the other side, Japanese, German, Italian are forecast to lose market share in the global e-economy. Such changes are of course highly relevant for the decision which language to study and/or to include in the curriculum of schools and universities. The general picture seems clear, however: Multilingualism will become increasingly important, and the days of the hegemony of only one language are probably over. Against the background of 
these general trends: How is the situation in Malaysia, and in particular in Sarawak?

\section{Case Study: Long-Term Trends of Language Use in Publications on Sarawak, 1810-2016}

Sarawak is an interesting example of the long-term study of linguistic choice in insular Southeast Asia. Its fundamental historical foundation is determined by non-European languages, namely mainly Austronesian languages belonging to the Western Malayo-Polynesian group. Examples are Malay and Iban. The bibliography of Collins (1990) on the Malay dialects of Sarawak provides a good entry point into the field of linguistic research on Sarawak. From the $19^{\text {th }}$ century onward, English influences are becoming highly important, leading for some time to a dichotomy of English as the language of print publications and Austronesian languages mostly used in oral settings. At a closer glance, however, Chinese (Lee Ching Seng, n.d.) and Malay also play a role as written languages in this preIndependence period, be it in manuscripts, books, or newspapers. The situation changed when Sarawak formed Malaysia together with North Borneo (Sabah), the Federation of Malaya, and Singapore in 1963 and the national language of Malaysia, Malay, became much more relevant for Sarawak.

In this study, I focus first on the linguistic choice of book publications on Sarawak since the early $19^{\text {th }}$ century to the present day. For the period before Independence, libraries outside of Sarawak have the most comprehensive holdings on Sarawak. Hence, as a first step, I conduct an analysis of book publications (only printed books), as document by WorldCat. This database makes thousands of library catalogues accessible, most of them, however, in the more developed countries with digitised library catalogues and generous funding for big library collections, which creates a bias towards libraries from the Anglosphere. English-language publications on Sarawak are therefore most likely to be included, while uncertainties remain with publications that were produced and collected in countries such as Russia, Italy, the Arabic countries, China, Indonesia, etc. since most of their library catalogues are not searchable through WorldCat. 
Figure 2: Languages of Print Books on Sarawak, 1810-2009, According to WorldCat

Languages of print books on Sarawak, decades 1810-2009

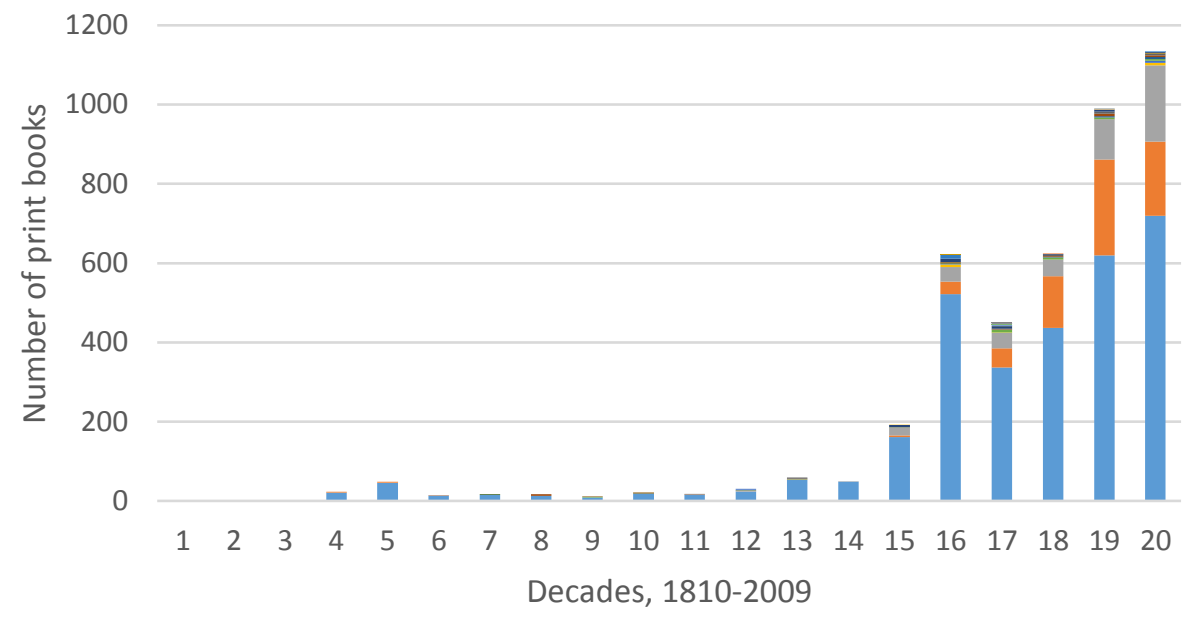

(Source: Various searches on WorldCat [n.d.].)

In order to facilitate the analysis of the broad trends, I conducted detailed searches on WorldCat for every decade from the last full decade (2000-2010) back to the first decade with an occurrence of print publications on Sarawak, which is the decade from 1810-1819. As Figure 2 demonstrates, the overall amount of print publications from Decade 1 (1810-19) through Decade 14 (1940-49) is relatively small (mostly less than 50 books per decade) and almost exclusively consisting of English-language publications. Table 1 gives the exact Worldcat numbers for the period before Sarawak co-formed Malaysia. As an interesting side aspect one can see that Japanese language publications on Sarawak are recorded in the decades from 1910-39, i.e. before the occupation during World War 2.

The problem with this database is, of course, that the encoding of publications is often not consistent. Many publications are being listed and counted more than once by the numerous librarians active in WorldCat. Also, the identification of Austronesian languages is often inaccurate. Nevertheless, the overall tendencies over the last two centuries are quite clear, especially the strong increase of publications on Sarawak since World War 2 and the increasing linguistic diversity since then. 
Table 1: Languages of Print Book Titles, 1810-1959, as Coded by Worldcat Libraries

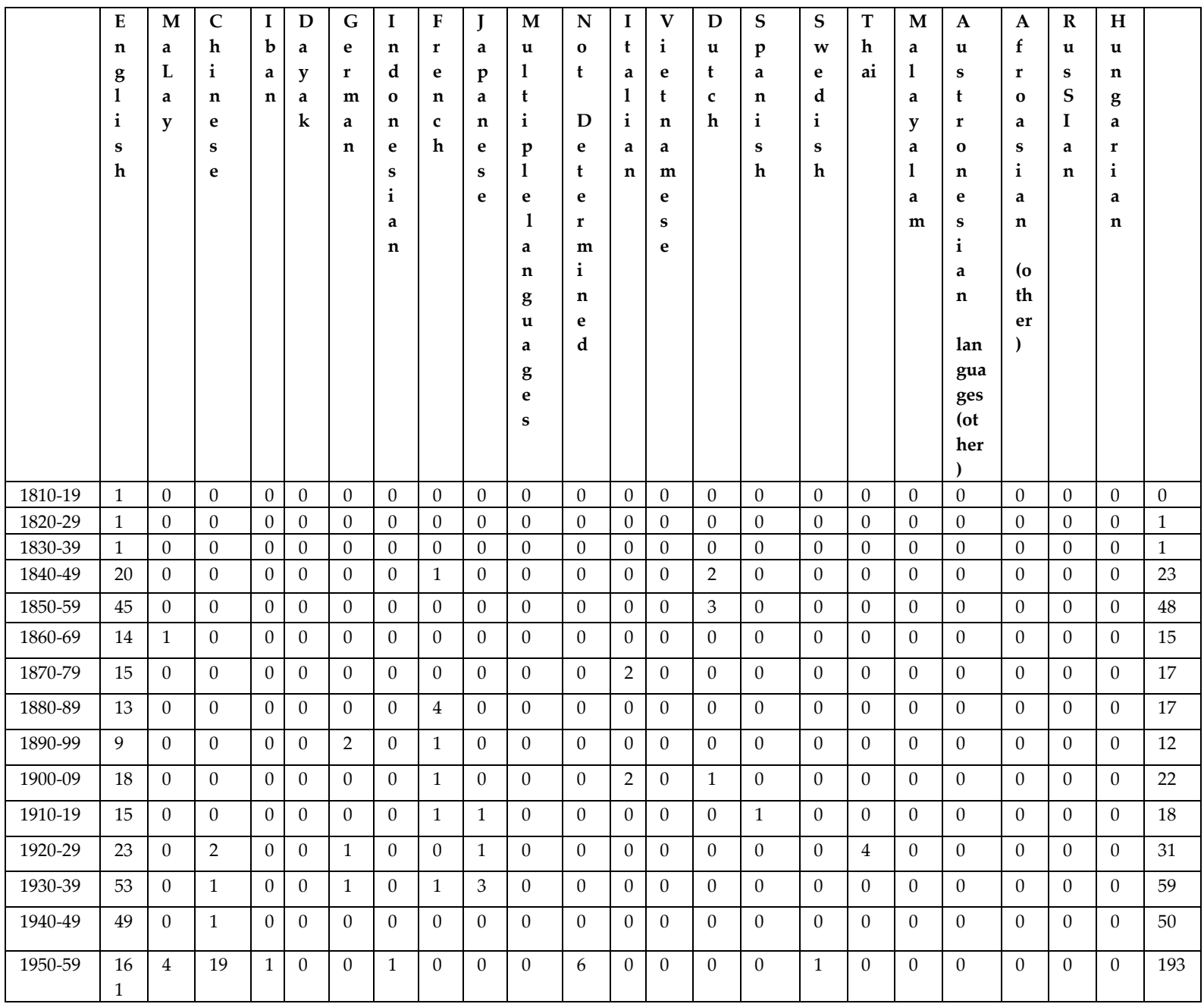

(Source: Various searches on WorldCat [n.d.].)

The overall picture changes profoundly from Decade 16 onward (1960-69), i.e. since Sarawak co-formed Malaysia. The overall output of print publications on Sarawak surpassed the mark of 1,000 in the decade of 2000-09, and the overall trend is still rising. At the same time, Malay and also Chinese have become important languages of print publications on Sarawak, at least according to WorldCat. The same caveat as above applies, as librarians around the world might sometimes confuse the names of languages, e.g. Malay and Malayam, or Malay and Indonesian, etc. 
Table 2: Languages of Print Book Titles, 1960-2009, as Coded by WorldCat Libraries

\begin{tabular}{|c|c|c|c|c|c|c|c|c|c|c|c|c|c|c|c|c|c|c|c|c|c|c|}
\hline & $\begin{array}{l}\text { E } \\
\text { n } \\
\text { g } \\
\text { l } \\
\text { i } \\
\mathrm{s} \\
\text { h }\end{array}$ & $\begin{array}{l}\mathbf{M} \\
\mathbf{a} \\
1 \\
\mathbf{a} \\
\mathbf{y}\end{array}$ & $\begin{array}{l}\text { C } \\
\text { h } \\
\text { i } \\
\text { n } \\
\text { e } \\
\text { s } \\
\text { e }\end{array}$ & $\begin{array}{l}\text { I } \\
\text { b }\end{array}$ & $\begin{array}{l}\mathrm{D} \\
\mathbf{a} \\
\mathbf{y} \\
\mathbf{a} \\
\mathbf{k}\end{array}$ & $\begin{array}{l}\mathrm{G} \\
\mathrm{e} \\
\mathrm{r} \\
\mathrm{m} \\
\mathrm{a}\end{array}$ & $\begin{array}{l}\text { e } \\
\text { s } \\
\text { i }\end{array}$ & $\begin{array}{l}\text { F } \\
\text { r } \\
\text { e } \\
\text { n } \\
\text { c } \\
\text { h }\end{array}$ & $\begin{array}{l}\mathrm{p} \\
\mathrm{a} \\
\mathrm{n}\end{array}$ & $\begin{array}{l}\text { M } \\
\text { u } \\
1 \\
\mathrm{t} \\
\mathrm{i} \\
\mathrm{p} \\
\mathrm{l} \\
\mathrm{e} \\
\mathrm{la} \\
\mathrm{n} \\
\mathrm{g} \\
\mathrm{u} \\
\mathrm{ag} \\
\text { es }\end{array}$ & $\begin{array}{l}\text { N } \\
o \\
t \\
d \\
\text { e } \\
\text { t } \\
\text { e } \\
\text { r } \\
\text { m } \\
\text { i } \\
\text { n } \\
\text { e } \\
d\end{array}$ & $\begin{array}{l}\text { a } \\
1 \\
\text { i }\end{array}$ & $\begin{array}{l}\text { V } \\
\text { i } \\
\text { e } \\
\text { t } \\
\text { n } \\
\text { a } \\
\text { m } \\
\text { e } \\
\text { s } \\
\text { e }\end{array}$ & $\begin{array}{l}D \\
u \\
t \\
c \\
h\end{array}$ & $\begin{array}{l}\text { S } \\
\text { p } \\
\text { a } \\
\text { n } \\
\text { i } \\
\text { s } \\
\text { h }\end{array}$ & $\begin{array}{l}\text { S } \\
\text { w } \\
\text { e } \\
\text { d } \\
\text { i } \\
\text { s } \\
\text { h }\end{array}$ & $\begin{array}{l}\text { T } \\
\text { h } \\
\text { a } \\
\text { i }\end{array}$ & $\begin{array}{l}\text { M } \\
\text { a } \\
\text { L } \\
\text { A } \\
\text { Y } \\
\text { A } \\
\text { L } \\
\text { a } \\
\text { m }\end{array}$ & $\begin{array}{l}\text { A } \\
\text { u } \\
\text { s } \\
\text { t } \\
\text { r } \\
\text { o } \\
\text { n } \\
\text { e } \\
\text { s } \\
\text { i } \\
\text { a } \\
\text { n } \\
\\
\text { lan } \\
\text { gu } \\
\text { ag } \\
\text { es } \\
\text { (ot } \\
\text { he } \\
\text { r) }\end{array}$ & $\begin{array}{l}\text { A } \\
\text { f } \\
\text { r } \\
\text { o } \\
\text { a } \\
\text { s } \\
\text { i } \\
\text { a } \\
\text { n } \\
\text { (o } \\
\text { th } \\
\text { er } \\
\text { ) }\end{array}$ & $\begin{array}{l}\text { R } \\
\text { u } \\
\text { s } \\
\text { s } \\
\text { i } \\
\text { a } \\
\text { n }\end{array}$ & $\begin{array}{l}\mathbf{H} \\
\mathbf{u} \\
\mathrm{n} \\
\mathrm{g} \\
\mathrm{a} \\
\mathbf{r} \\
\mathrm{i} \\
\mathrm{a} \\
\mathrm{n}\end{array}$ \\
\hline $1960-69$ & 522 & 31 & 37 & 6 & 1 & 2 & 1 & 2 & 0 & 1 & 8 & 0 & 0 & 0 & 0 & 0 & 0 & 0 & 9 & 1 & 0 & 1 \\
\hline $1970-79$ & 337 & 48 & 39 & 1 & 0 & 6 & 1 & 1 & 0 & 1 & 7 & 1 & 0 & 0 & 0 & 0 & 2 & 2 & 2 & 1 & 1 & 0 \\
\hline $1980-89$ & 437 & 130 & 42 & 0 & 0 & 5 & 1 & 2 & 3 & 0 & 3 & 0 & 0 & 2 & 0 & 0 & 0 & 0 & 0 & 0 & 0 & 0 \\
\hline $1990-99$ & 619 & 242 & 100 & 1 & 1 & 4 & 4 & 6 & 5 & 0 & 4 & 1 & 0 & 1 & 1 & 1 & 1 & 0 & 0 & 0 & 0 & 0 \\
\hline $\begin{array}{l}2000- \\
2009\end{array}$ & 719 & 188 & 192 & 6 & 5 & 5 & 5 & 4 & 4 & 3 & 2 & 1 & 1 & 0 & 0 & 0 & 0 & 0 & 0 & 0 & 0 & 0 \\
\hline
\end{tabular}

(Source: Various searches on WorldCat [n.d.].)

In order to obtain a clearer impression of the developments since World War 2, I conducted as a second step a much more refined analysis of the holdings of Malaysian academic libraries for this post-war period, as documented through MALCat, the Malaysian Academic Libraries Union Catalogue. Here I searched every individual year, and I checked the raw data, namely book title per book title, one by one, correcting multiple counts of publications, inaccurate language attributions etc. 
Figure 3: Market Share of Languages of Books on Sarawak, 1945-2016, According to MALCat

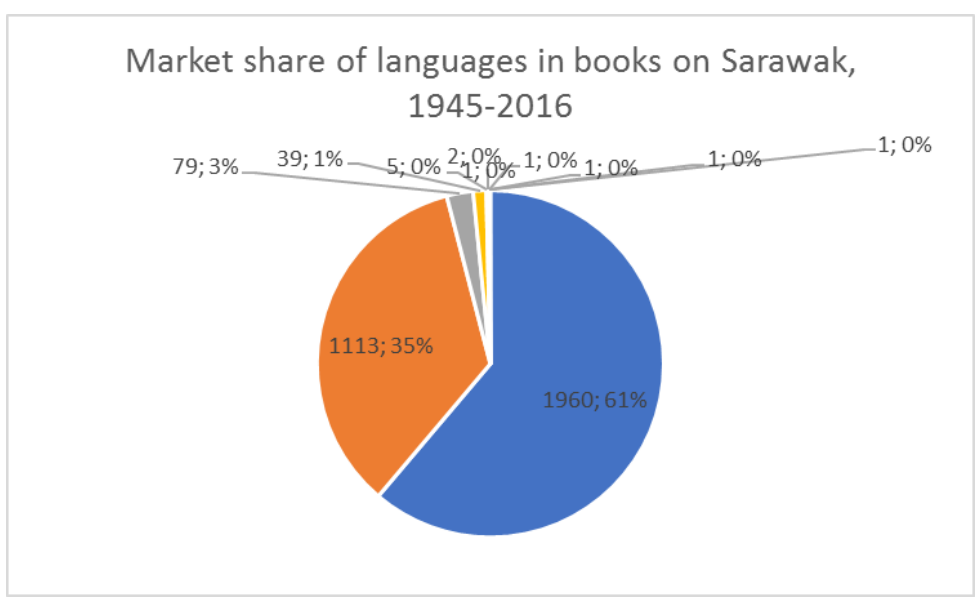

(Legend: English in orange, Malay in blue.)

Figure 3 demonstrates that English has lost its previous quasi-monopoly in book publications on Sarawak since World War II until 2016. In the total of this period, Malay has a market share of $35 \%$ (1,113 books), Chinese of $3 \%$ (79 books), and Iban $1 \%$ (39 books).

Figure 4: Market Share of Individual Languages in Book Publications on Sarawak, 1945-2016

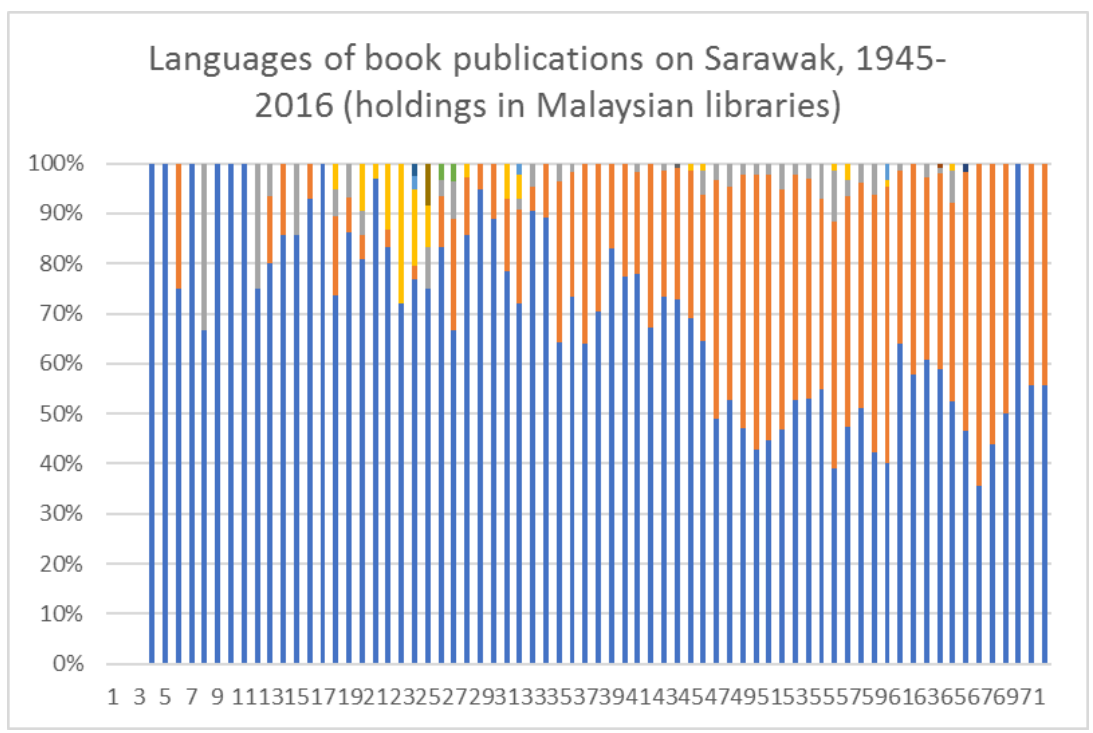

(Legend: English in blue, Malay in orange, Iban in orange.) 
As Figure 4 demonstrates, there is a clear long-term pattern in the linguistic choice of book publications on Sarawak. English is continuously losing ground and Malay conversely gaining importance, until around the year 47 after World War 2 , which is around 1992. Ever since the two languages are almost every year evenly strong in terms of book publications on Sarawak. Chinese, on the other hand, seems to have had strong periods from 1950 through the early 1960s, and again in the 1990s through the 2000s, while MALCat does not document any Chinese language publications on Sarawak since around 2010. Languages from Sarawak, especially Iban, appear mostly in the 1960s, most often in publications of the Borneo Literature Bureau, and again in the early 2000s in publications by the Tun Jugah Foundation, the Dayak Cultural Foundation and other institutions and publishing presses active in Sarawak A question for further research is whether local Chinese-language publications from Sarawak have indeed ceased to exist, or whether they just by coincidence happened to not be collected by the librarians in the concerned academic libraries.

Figure 5: Number of Book Publications on Sarawak, 1945-2016

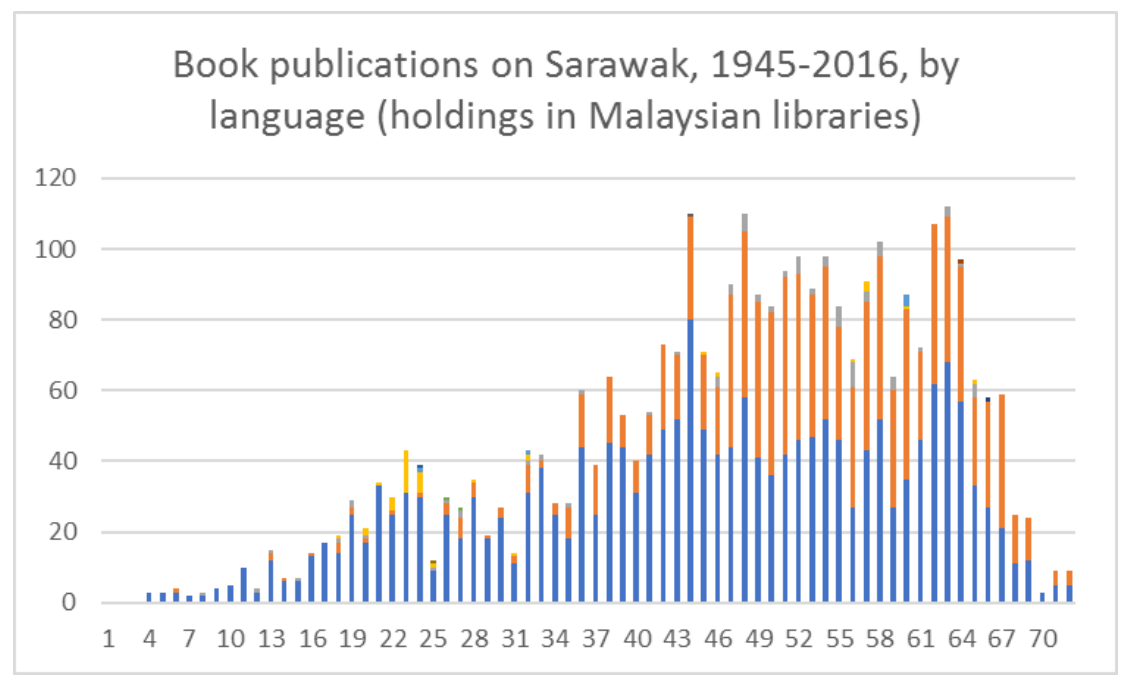

(Legend: English in blue, Malay in orange.)

Figure 5 displays the absolute numbers of book publications on Sarawak after World War II, as documented by MALCat. Accordingly, there is a strong growth mostly in Malay language publications since the year 37 (=1982), reaching equal shares in the market since ca. the year 46 (1991). However, MALCat also documents a sharp decline of Sarawak-related holdings in Malaysian academic libraries, both in English and Malay, since ca. the year 65 (=2010). The reasons are 
unclear. Possibly, a backlog of a few years is normal for any library system since it usually takes some time until libraries acquire books, process them and feed the data into MALCat or similar union catalogues. For our inquiry here, the most important aspect, however, is that the market share between English and Malay remains relatively stable, even in the last few years of decreasing holdings on Sarawak.

\section{Linguistic Choice in Journal Publications on Sarawak}

In the second part of this paper, I would like to compliment the results of Part I by now focusing on the linguistic choice in Malaysian academic journal publications on Sarawak. My sample consists of all the journals covered by MyCite, the Malaysian Abstracting and Indexing database for more than 34,000 articles from 138 journals. - The limitation of this database is, of course, that for copyright reasons it only covers journals under the jurisdiction of the Malaysian Ministry of (Higher) Education. Other journals, including in Sarawak itself, but also abroad, are not covered. On the other hand, many of the articles covered in MyCite are immediately downloadable as PDFs, which makes this site one of the most important facilitators and gatekeepers in Malaysian Studies both in Malaysia and abroad. In terms of methodology, I conducted a comprehensive search with the keyword "Sarawak", and then counted all items per year, before analysing the sample further. 165 articles with the keyword "Sarawak" could be thus identified, from the period 1989-2016, of which 92 (55.8 \%) are in English, 74 (44.2 \%) in Malay.

Figure 6: Linguistic Choice in Malaysian Articles on Sarawak, 1989-2016, According to MyCite

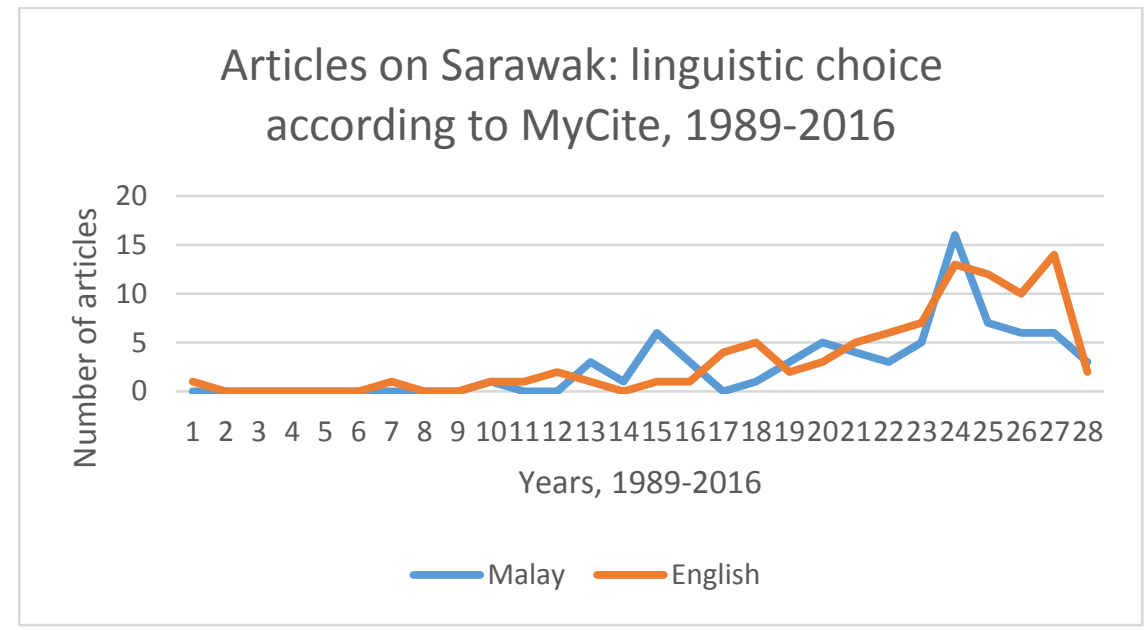


As Figure 6 demonstrates, a clear general overall increase of journal publications on Sarawak can be observed, both in English and Malay. The relative decline in the last years covered might be again related to the normal backlog in processing new publications in the library system. More important, in terms of linguistic choice, is the overall stability in the respective market share between English and Malay. This is illustrated in Figure 7.

Figure 7: Market Shares of English and Malay in Malaysian Journal Articles on Sarawak, 1989-2016

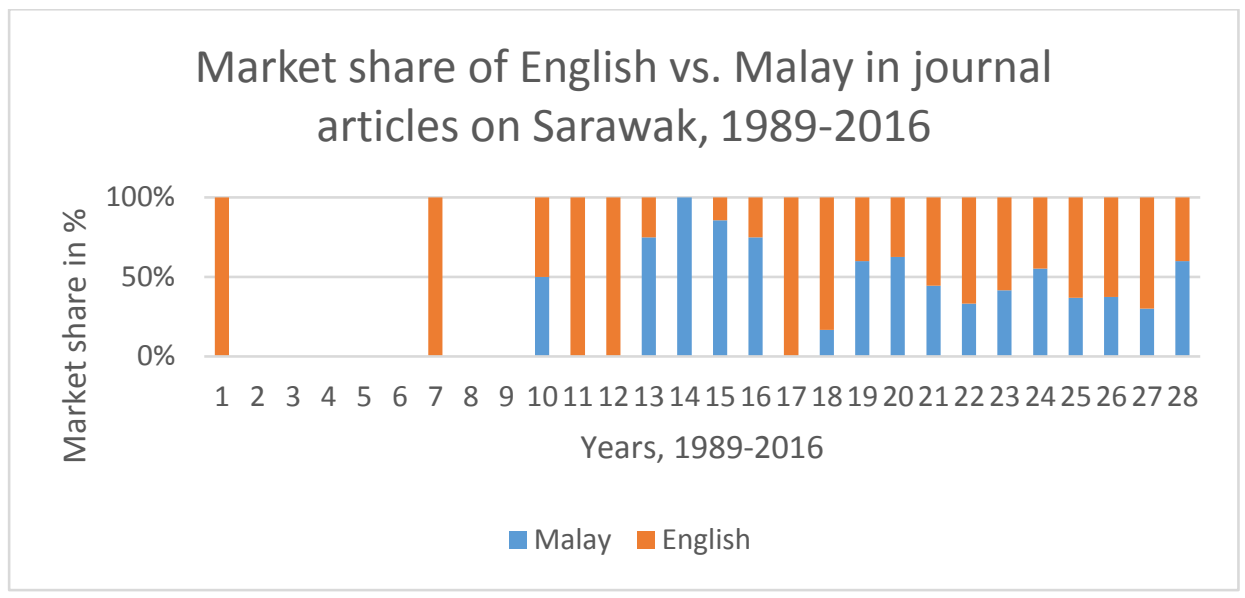

The market share of Malay-language publications (44.2\%) is remarkable if we compare the coverage of Sarawak in MyCite with that in the most important international Abstracting and Indexing database in international Asian Studies, namely the (American) Bibliography of Asian Studies (BAS). As Figure 8 shows, is the depth of coverage of the BAS much smaller than that of MyCite. In terms of quantity, much fewer publications are covered, and in terms of linguistic choice, no publication in a language other than English is considered, including Malay. This is partly understandable since the knowledge of languages from Southeast Asia is not very developed in America. On the other hand, it is a bit disturbing for the quality of research in American Studies on Malaysia if almost half of the expertise on a given topic, in this case, Sarawak, is being neglected by the major scholarly database. 
Figure 8: Articles on Sarawak as Covered by the BAS, 1966-2016

\section{Articles on Sarawak according to BAS, 1966-} 2016

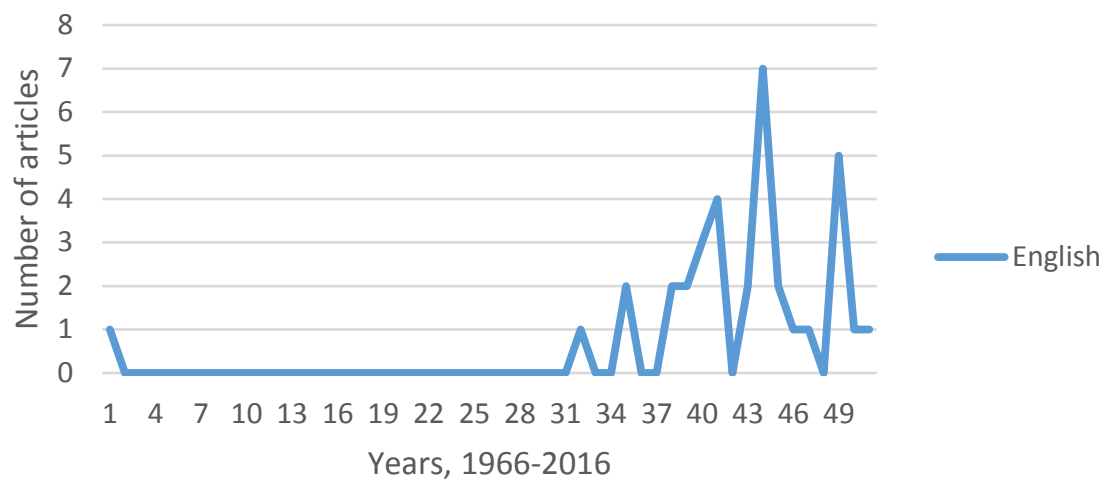

This leads to the question of whether the linguistic choice of the articles on Sarawak that MyCite is representing is related to the field of study. A short random probe reveals that recent Malay language articles on Sarawak tend to emphasise aspects such as identity, language, religion, and culture. In contrast, recent English-language articles in MyCite appear rather scientific, featuring keywords such as "ground temperature", "mangroves", "Menthol brand cigarettes", etc.

Inspired by this first random probe, I went through all 165 articles on Sarawak in the sample and sorted each according to discipline and faculty. The result is shown in Figures 9 and 10.

Figure 9: Linguistic Choice in Articles on Sarawak, 1989-2016, According to MyCite (Sorting by Year)

\begin{tabular}{|l|l|l|}
\hline & Malay & English \\
\hline 1989 & 0 & 1 forestry \\
\hline 1990 & 0 & 0 \\
\hline 1991 & 0 & 0 \\
\hline 1992 & 0 & 0 \\
\hline 1993 & 0 & 0 \\
\hline 1994 & 0 & 0 \\
\hline 1995 & 0 & 1 forestry \\
\hline 1996 & 0 & 0 \\
\hline 1997 & 0 & 0 \\
\hline 1998 & 1 fishing & 1 public health \\
\hline
\end{tabular}




\begin{tabular}{|c|c|c|}
\hline 1999 & 0 & 1 anthropology \\
\hline 2000 & 0 & 2 (1 linguistics, 1 geology) \\
\hline 2001 & $\begin{array}{l}3 \text { (1 fishing, } 1 \text { geography, } 1 \\
\text { linguistics) }\end{array}$ & 1 development studies \\
\hline 2002 & 1 anthropology & 0 \\
\hline 2003 & 7 (7 politics) & 1 politics \\
\hline 2004 & 3 (1 economics, 2 linguistics) & 1 public health \\
\hline 2005 & 0 & $\begin{array}{l}4 \text { (1 public health, } 1 \text { law, } 1 \text { education, } 1 \\
\text { history) }\end{array}$ \\
\hline 2006 & 1 linguistics & $\begin{array}{l}5 \text { (1 politics, } 1 \text { environmental studies, } \\
\text { psychiatry, } 1 \text { public health, } 1 \text { biology }\end{array}$ \\
\hline 2007 & $\begin{array}{l}3 \text { (1 environmental studies, } 1 \\
\text { geography, } 1 \text { public health) }\end{array}$ & 2 (1 environmental studies, 1 fishing) \\
\hline 2008 & $\begin{array}{l}5 \text { (1 fishing, } 2 \text { economics, } 1 \text { geology, } \\
1 \text { linguistics) }\end{array}$ & $\begin{array}{l}3 \text { (1 education, } 1 \text { sociology, } 1 \text { public } \\
\text { health) }\end{array}$ \\
\hline 2009 & $\begin{array}{l}4 \text { (1 history, } 1 \text { geography, } 1 \text { Islamic } \\
\text { studies, } 1 \text { education) }\end{array}$ & $\begin{array}{l}5 \text { (1 economics, } 2 \text { tourism studies, } 1 \text { law, } 1 \\
\text { politics) }\end{array}$ \\
\hline 2010 & 3 (2 linguistics, 1 literature) & $\begin{array}{l}6 \text { (1 linguistics, } 2 \text { biology, } 1 \text { public health, } \\
1 \text { musicology, } 1 \text { sociology) }\end{array}$ \\
\hline 2011 & $\begin{array}{l}5 \text { (1 politics, } 1 \text { history, } 2 \text { literature, } 1 \\
\text { linguistics) }\end{array}$ & $\begin{array}{l}7 \text { ( } 1 \text { public health, } 1 \text { agriculture, } 2 \\
\text { environmental studies, } 2 \text { geology, } 1 \\
\text { biology) }\end{array}$ \\
\hline 2012 & $\begin{array}{l}16 \text { ( } 4 \text { politics, } 1 \text { architecture, } 7 \\
\text { linguistics, } 2 \text { history, } 1 \text { musicology, } 1 \\
\text { anthropology) }\end{array}$ & $\begin{array}{l}13 \text { ( } 3 \text { public health, } 5 \text { biology, } 3 \\
\text { environmental studies, } 1 \text { linguistics, } 1 \\
\text { politics) }\end{array}$ \\
\hline 2013 & $\begin{array}{l}7 \text { ( } 5 \text { linguistics, } 1 \text { anthropology, } 1 \\
\text { politics) }\end{array}$ & $\begin{array}{l}12 \text { ( } 5 \text { public health, } 4 \text { biology, } 1 \\
\text { economics, } 1 \text { tourism studies, } 1 \\
\text { environmental studies) }\end{array}$ \\
\hline 2014 & $\begin{array}{l}6 \text { (1 geography, } 1 \text { Islamic studies, } 1 \\
\text { anthropology, } 1 \text { musicology, } 1 \\
\text { history, } 1 \text { agriculture) }\end{array}$ & $\begin{array}{l}10 \text { ( } 1 \text { sociology, } 2 \text { environmental studies, } 1 \\
\text { linguistics, } 3 \text { public health, } 3 \text { biology) }\end{array}$ \\
\hline 2015 & $\begin{array}{l}6 \text { ( } 2 \text { history, } 1 \text { geography, } 1 \text { Islamic } \\
\text { studies, } 1 \text { linguistics, } 1 \text { literature }\end{array}$ & $\begin{array}{l}14 \text { ( } 4 \text { environmental studies, } 2 \text { public } \\
\text { health, } 4 \text { biology, } 2 \text { civil engineering, } 1 \\
\text { agriculture, } 1 \text { politics) }\end{array}$ \\
\hline 2016 & 4 (1 geography, 3 linguistics) & 2 (1 public health, 1 civil engineering) \\
\hline Total & 75 & 92 \\
\hline
\end{tabular}

(Source: Various searches on MyCite [n.d.].) 
Figure 10: Linguistic Choice in MyCite-Covered Articles on Sarawak According to Faculty and Discipline, 1989-2016 (Overall Sorting)

\begin{tabular}{|c|c|c|c|c|}
\hline Faculty & Discipline & $\begin{array}{l}\text { Malay articles } \\
\text { in MyCite }\end{array}$ & $\begin{array}{l}\text { English } \\
\text { articles in } \\
\text { MyCite }\end{array}$ & Sum \\
\hline \multirow[t]{6}{*}{ Humanities } & History & 7 & 1 & 8 \\
\hline & Islamic studies & 3 & 0 & 3 \\
\hline & Linguistics & 24 & 4 & 28 \\
\hline & Literature & 4 & 0 & 4 \\
\hline & Musicology & 2 & 1 & 3 \\
\hline & & 40 & 6 & 46 \\
\hline \multirow[t]{9}{*}{ Social sciences } & Anthropology & 4 & 1 & 5 \\
\hline & $\begin{array}{l}\text { Development } \\
\text { studies }\end{array}$ & 0 & 1 & 1 \\
\hline & Economics & 4 & 2 & 6 \\
\hline & Geography & 6 & 0 & 6 \\
\hline & Law & 0 & 2 & 2 \\
\hline & Politics & 12 & 5 & 17 \\
\hline & Sociology & 0 & 3 & 3 \\
\hline & Tourism studies & 0 & 3 & 3 \\
\hline & & 26 & 17 & 43 \\
\hline \multirow{9}{*}{$\begin{array}{l}\text { Sciences and } \\
\text { engineering }\end{array}$} & Agriculture & 1 & 2 & 3 \\
\hline & Architecture & 1 & 0 & 1 \\
\hline & Biology & 0 & 20 & 20 \\
\hline & Civil engineering & 0 & 3 & 3 \\
\hline & $\begin{array}{l}\text { Environmental } \\
\text { studies }\end{array}$ & 1 & 14 & 15 \\
\hline & Fishing & 3 & 1 & 4 \\
\hline & Forestry & 0 & 2 & 2 \\
\hline & Geology & 1 & 3 & 4 \\
\hline & & 7 & 45 & 52 \\
\hline \multirow[t]{3}{*}{ Medicine } & Psychiatry & 0 & 1 & 1 \\
\hline & Public health & 1 & 21 & 22 \\
\hline & & 1 & 22 & 23 \\
\hline TOTAL & & 75 & 92 & 167 \\
\hline
\end{tabular}

(Source: Various searches on MyCite [n.d.].) 
The overall result is that not only the majority of Sarawak-related articles from the humanities (history, Islamic studies, linguistics, literature, and musicology) is in Malay. Also, the majority of articles from four disciplines in the Social Sciences is in Malay, namely anthropology, economics, geography, and politics. A majority for English can be found in development studies, law, sociology, and tourism studies, as well as in all disciplines from the sciences and engineering, as well as medicine.

\section{General Discussion and Conclusion}

This study found that in general, English has lost its formerly quasi-monopoly in book publications on Sarawak in the period since the formation of Malaysia (1963), in particular since the 1980s, although it is still in a very important position. Malay has become an increasingly relevant language of book publications on Sarawak. There is also an interesting body of publications in Chinese and Austronesian languages from Sarawak. Of particular interest are book publications in Iban, including from the Tun Jugah Foundation, which contributes to reviving Iban as book language since the mid-2000s. Overall, there seems to be a rather stable equilibrium of languages since the early 2000s. This linguistic diversity in publications on Sarawak implies that scholars working on Sarawak should be fluent in more than one language in order to read the book publications on that state.

In terms of academic journal articles on Sarawak, a similarly stable equilibrium between English and Malay has been found in journals covered by MyCite. The specialised scholarly discourse on Sarawak in of the represented contributions from the humanities and most of the social sciences is mostly conducted in Malay, not English, while a few publications in the social sciences and in all of the sciences, engineering, and medicine, are in English.

Multilingualism is therefore of great importance for Sarawak Studies. Among the implications for international programs of Southeast Asian Studies is that it is not sufficient to only be able to read English-language sources in the mentioned disciplines in the humanities and social sciences where the expert discourse in national journals is predominantly in Malay. This means that Malay or Indonesian language courses should be essential for anybody with interest in Sarawak, while electives in other languages should be offered for more specialised interests. However, also English is part of the linguistic reality of Sarawak, as well, of course, important for most academic disciplines as a working language.

An indirect implication of these findings is that libraries of international Southeast Asian Studies should emphasise more on non-English publications on 
Southeast Asia, including local language publications on Sarawak and other parts of Malaysia. Since non-Asian Abstracting and Indexing databases such as the Bibliography of Asian Studies tend to exclude non-English sources, international Southeast Asian Studies should increase the use of Southeast Asian bibliographic resources such as MyCite, MALCat etc. At the same time, it remains to be seen whether the recent emphasis in Malaysian universities to publish articles in international journals in English will alter the balance of linguistic choice in scholarly publications on Sarawak again.

\section{References}

Collins, J. T. (1990). Bibliografi Dialek Melayu di Pulau Borneo. Kuala Lumpur: Dewan Bahasa dan Pustaka.

Graf, A. (2009). Indexing a Field: the Case of Indonesian and Malaysian Studies. RIMA: Review of Indonesian and Malaysian Affairs, 43(2), 191-221.

Graf, A. (2010). Bahasa Melayu dan Jurnal dari Malaysia Bidang Ilmu Kemanusiaan dan Sains Sosial Dalam Indeks Antarabangsa. Penang: Universiti Sains Malaysia Press.

Graf, A. (2011). Beyond 2020: Indonesian and Malay in a New Linguistic World Order. Kemanusiaan: The Asian Journal for Humanities, 18(1), 77-100. Retrieved 28 March 2017, from http://web.usm.my/kajh/vol\%2018.1.2011/KAJH\%2018.1.2011 \%205.pdf

Graf, A. (2015). Takkan Melayu Hilang di Dunia: Realiti dan Harapan. In Pusat Bahasa Melayu, Kementerian Pendidikan Singapura (Ed.), Siri Ceramah Arif Budiman, Vol. 3 (pp. 28-63). Singapore: Unit Bahasa Melayu dan Cawangan Bahasa Ibunda, Bahagian Perancangan dan Pembangunan Kurikulum, Kementerian Pendidikan Singapura.

Inside WorldCat. (n.d.). OCLC.org. Retrieved 28 March 2017, from https://www.oclc.org/en/worldcat/inside-worldcat.html

Lee Ching Seng. (n.d.). The Chinese Overseas Resources in Singapore and Malaysia: Sharing Information through the Internet. Retrieved 28 March 2017, from

http://www.lib.nus.edu.sg/chz/chineseoverseas/Chinese\%20Overseas\%2 0Resources\%20in\%20Singapore\%20and\%20Malaysia1.pdf

Malaysian Academic Library Union Catalog (MALCat). (n.d.). Retrieved 28 March 2017, from http://malcat.uum.edu.my/kip/

Malaysian Citation Index (MyCite). (n.d.). Retrieved 8 March 2017, from http://www.mycite.my/ 
Muhammad Haji Salleh. (2003, 26-27 September). Hang Tuah Bercakap Oghang Puteh: Terjemahan dan Penjelmaan Hang Tuah dalam Bahasa Eropah. Paper presented at Seminar Kebangsaan Hang Tuah, Dewan Budaya, Universiti Sains Malaysia, Penang, Malaysia. Retrieved 28 March 2017, from http://eprints.usm.my/13/1/MHS1.pdf

Seidel, B., \& Chamdy, L. (2016). Donald Trump and the Future of Globalization. Brookings Institution's website. Retrieved 28 March 2017, from https://www.brookings.edu/blog/up-front/2016/11/18/donald-trumpand-the-future-of-globalization

Syed Hussein Alatas. (1977). The Myth of the Lazy Native: A Study of the Image of the Malays, Filipinos, and Javanese from the 16th to the 20th Century, and its Function in the Ideology of Colonial Capitalism. London: Cass.

Translated. (n.d.). Retrieved 17 December 2019, from https://translated.com/welcome

WorldCat. (n.d.). Retrieved 9 January 2017, from https://www.worldcat.org/ 